\title{
PROBLEMS IN RADIOCARBON DATING OF SOILS
}

\section{O. A. CHICHAGOVA and A. E. CHERKINSKY}

Institute of Geography, Russian Academy of Sciences, Staromenetnyi 29, Moscow 109017 Russia

\begin{abstract}
We discuss our progress in three principal applications of ${ }^{14} \mathrm{C}$ dating of recent and fossil soils: 1) new methods; 2) problems of interpreting ${ }^{14} \mathrm{C}$ soil data (e.g., ${ }^{14} \mathrm{C}$ age of soils, age of soils, duration of humus formation, rate of carbon cycling); and 3$){ }^{14} \mathrm{C}$ analysis of soil organic matter (OM) in pedology and paleogeography (e.g., soil genesis and evolution, humus formation and $\mathrm{OM}$ metamorphosis, geochronology and stratigraphy of Late Pleistocene and Holocene sediments). We suggest exploring the above issues in the analysis of each ${ }^{14} \mathrm{C}$ profile in conjunction with paleogeographical data, and by simulation of the carbon cycle in each type of profile.
\end{abstract}

\section{INTRODUCTION}

The radiocarbon dating of humus in recent and fossil soils in the former USSR began in the 1960s, under the initiative and guidance of I. P. Gerasimov, who established a ${ }^{14} \mathrm{C}$ laboratory in 1971 in the Institute of Geography, USSR Academy of Sciences. Over the past decade, considerable advances have been made in using ${ }^{14} \mathrm{C}$ dating for studying organic matter (OM) and soil age in interpretations and applications in pedology and paleogeography. Solving questions of the geochronology and stratigraphy of the Late Pleistocene, paleogeographic reconstruction and correlation of these with human activity in the northern hemisphere, soil genesis and evolution, humus formation and metamorphism of OM, and the rate of elementary soil processes (ESP) require the use of data obtained by ${ }^{14} \mathrm{C}$ dating soil $\mathrm{OM}$.

Even though ${ }^{14} \mathrm{C}$ dating soil $\mathrm{OM}$ is complicated, the reliability of this method was ensured by the concurrence of most dates of fossil soils with historical, geological and archaeological analogs (Gerasimov 1969; Gerasimov and Chichagova 1971). However, Gerasimov also notes widely divergent ${ }^{14} \mathrm{C}$ dates for recent soils based on humus matter. Soil OM is composed of fractions differing in structure, genesis and age, and is exposed to various diagenetic processes related to the transformation of humus as a result of the biological carbon cycle (in recent soils) as well as with the time and conditions of burial (in fossil soils).

Gerasimov (1969) introduced the concept of relative and absolute ${ }^{14} \mathrm{C}$ determination of soil age by dividing soil carbon into "biologically active" and "biologically inert" categories. The active carbon can be used to estimate the circulation rate of biological matter in various genetic types of soils and is the index of their relative age; inert carbon, which derives from biological circulation, becomes relict, and can be characteristic of absolute soil age.

Gerasimov and Chichagova (1971) suggested a genetic interpretation of ${ }^{14} \mathrm{C}$ dates for humus of recent and fossil soils. The dates for fossil soils can conventionally estimate "the absolute age of ancient soil", and more precisely, the maximum age of their former existence or the time of burial; for recent soils, the ${ }^{14} \mathrm{C}$ age of humus (its oldest fractions) can express both the relative as well as the absolute age, depending on the components of soil mass, recent or relict, of its context.

Chichagova (1985) reviewed interpretive literature on ${ }^{14} \mathrm{C}$ analyses in paleosols. Two methods can be used to evaluate ${ }^{14} \mathrm{C}$ data of soil OM:

1. Constructing an adequate model of carbon circulation and, from this, determining the real duration of humus formation (Zavel'sky 1975; Lobo and Flexor 1974)

2. Defining the inert fraction of the humus; its ${ }^{14} \mathrm{C}$ age would be as close as possible to the true age (Gerasimov and Chichagova 1971; Arslanov and Kozyreva 1976; Scharpenseel 1971). 


\section{DETERMINING THE DURATION OF HUMUS FORMATION}

"Soil age" has not yet been applied definitively to recent soil. The older age limit of recent soil corresponds to the modern period of pedogenesis, but soil continues to develop, evolving in time with changes in soil formation from the beginning, or its younger age limit. The major portion of recent soils experience various bioclimatic stages with considerable changes in trends and intensities of ESP. Thus, most recent soils are polygenetic, and it is very difficult or practically impossible to determine the beginning of their formation.

Targul'yan (1982) proposed the term characteristic time for a period of time necessary for a natural body, feature or process to develop under a stable combination of environmental factors, and to come to equilibrium or quasi-equilibrium with these factors. With a change in any of these factors, characteristic time enables us to identify a new state of quasi-equilibrium. The total absolute age (Ta) (Tarqul'yan 1982) of monogenetic soil, or a particular age of an evolutionary stage of polygenetic soil, is equal to the sum of characteristic time $\left(\mathrm{t}_{\mathrm{m}}\right)$ and time of the existence of soil in a quasi-equilibrium state $\left(t_{c}\right)$

$$
\mathrm{Ta}=\mathrm{t}_{\mathrm{m}}+\mathrm{t}_{\mathrm{c}} \text {. }
$$

The total absolute age $\left(\mathrm{Ta}^{1}\right)$ of polygenetic soil equals the sum of ages of separate constituents

$$
\mathrm{Ta}^{1}=\sum_{\mathrm{i}=1}^{\mathrm{n}} \mathrm{t}_{\mathrm{mi}}+\mathrm{t}_{\mathrm{ci}}
$$

The characteristic time of soil formation processes of monogenetic soil determines the duration of the stage of its formation. Each feature or process has its own particular time, the duration of which depends on external environmental conditions and the nature of the feature or process.

\section{DYNAMICS OF ORGANIC PROFILE FORMATION OF RECENT SOIL}

For simplicity, we shall assume that soil develops according to the monogenetic model. During the initial period of profile formation, $\mathrm{OM}$ is accumulating, i.e., the rate of humification of plant and animal remains $\left(\mathrm{V}_{\mathrm{r}}\right)$ exceeds the rate of mineralization of humus (Fig. 1)

$$
\left(\mathrm{V}_{\mathrm{m}}\right): \mathrm{V}_{\mathrm{r}}>\mathrm{V}_{\mathrm{m}} \text {. }
$$

Comparatively mineralization-resistant fractions of the $\mathrm{OM}$ accumulate, stabilized by the mineral content of the soil. Because of the major introduction of organic remains and higher biochemical activity in the upper horizons, accumulation is more intensive there, and the processes of humus formation come more quickly to quasi-equilibrium. For the lower horizons, where plant remains are fewer and biochemical activity is less, the period of humus development is much longer.

When humus formation reaches a state of quasi-equilibrium, the rate of humus formation, or that of one of its fractions, reaches equilibrium with the rate of mineralization, and humus accumulation ends. The horizon can exist for an indefinite period of time in invariable environmental conditions $\left(\mathrm{V}_{\mathrm{g}}=\mathrm{V}_{\mathrm{m}}\right)$.

\section{SPECIFIC HUMIC ACTIVITY}

At the first moment of humus formation, the ${ }^{14} \mathrm{C}$ activity is the same as the specific biotic activity, which is taken as constant in time, and equal to the specific activity of atmospheric ${ }^{14} \mathrm{C}$. 

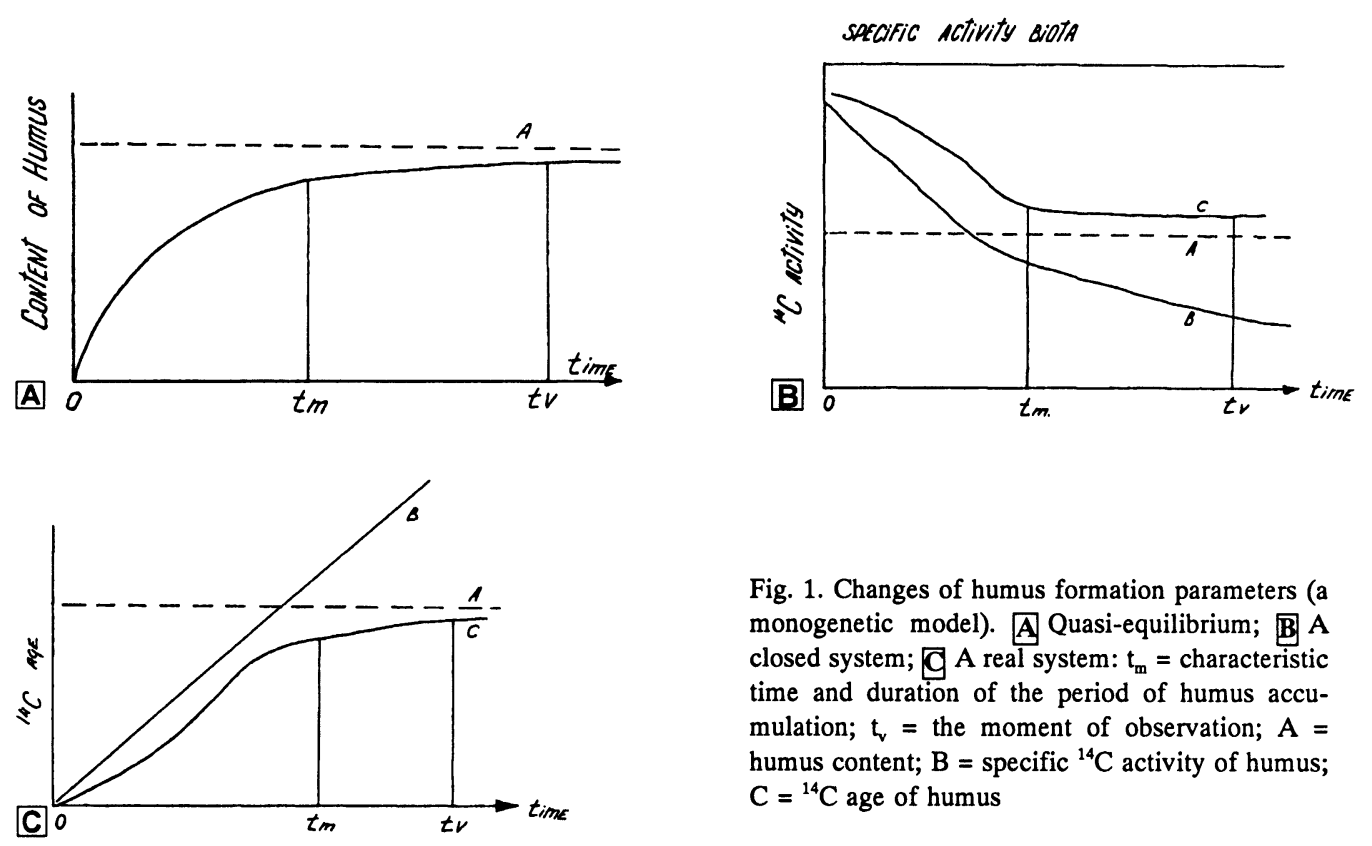

Fig. 1. Changes of humus formation parameters (a monogenetic model). A Quasi-equilibrium; B A closed system; $\mathrm{d}$ A real system: $\mathrm{t}_{\mathrm{m}}=$ characteristic time and duration of the period of humus accumulation; $\mathrm{t}_{\mathrm{v}}=$ the moment of observation; $\mathrm{A}=$ humus content; $\mathrm{B}=$ specific ${ }^{14} \mathrm{C}$ activity of humus; $\mathrm{C}={ }^{14} \mathrm{C}$ age of humus

Then, as $\mathrm{OM}$ accumulates, ${ }^{14} \mathrm{C}$ starts decreasing because of radioactive decay in the biologically stable fractions, which are, to a small extent, subject to mineralization. If such relatively stable "fresh" fractions of plant remains did not form and were not deposited continually, the specific activity of the original humus fractions would change exponentially according to the law of radioactive decay (closed system). In recent soil (open system) at the stage of formation, "fresh" partially conserved humus is added to the fixed humus. At the initial moment of soil formation, the proportion of newly formed and fixed "fresh" humus (with specific biotic activity) is large, and as a result of radioactive decay and mineralization, its specific activity decreases insignificantly. As humus formation nears quasi-equilibrium (as OM saturates the mineral portion), the decrease in specific activity will be more noticeable. Because absolutely stable fractions do not form as a result of humification, "old" humus partly mineralizes and "fresh" humus replaces it.

At a given characteristic time for each humus horizon as well as for separate humus fractions, the amount of the "young" ${ }^{14} \mathrm{C}$ in the humus becomes roughly equal to the amount of mineralized "old" ${ }^{14} \mathrm{C}$ plus the decrease of ${ }^{14} \mathrm{C}$ from radioactive decay

$$
Q_{p}=Q_{m}+Q_{r}
$$

where $Q_{p}=$ amount of ${ }^{14} \mathrm{C}$ deposited with the "young" humus

$\mathrm{Q}_{\mathrm{m}}=$ amount of ${ }^{14} \mathrm{C}$ mineralized with the "old" humus

$\mathrm{Q}_{\mathrm{r}}=$ decrease of ${ }^{14} \mathrm{C}$ due to radioactive decay.

Thus, the process of change of specific humic activity with regard to ${ }^{14} \mathrm{C}$ also reaches equilibrium or quasi-equilibrium. Consequently, for the finally mature monogenetic soil in any of its horizons, constant, specific ${ }^{14} \mathrm{C}$ activity of humus develops independently of the duration of the period of quasi-equilibrium. 
After measuring this specific activity $\left(\mathrm{I}_{\mathrm{x}}\right)$, and calculating the ${ }^{14} \mathrm{C}$ age of humus or some other fraction

$$
T=\frac{-1}{\lambda} \ln \frac{I_{x}}{I_{0}}
$$

where $\quad \mathrm{T}={ }^{14} \mathrm{C}$ age of humus or any of its fractions

$\lambda=$ radioactive decay constant

$I_{o}=$ specific activity of a standard sample,

we actually determine the characteristic time or maximum duration of the humus-accumulation stage in the given horizon of monogenetic soil. We use the profile of a recent typical Chernozem soil as an example. Many researchers believe that Chernozems started developing in the Early to Middle Holocene when humus formation developed into a monogenetic profile. We dated humic acids (HA) of a Chernozem buried under and on the surface (background) of a Bronze Age mound. The age of the burial has been archaeologically dated to $3500 \mathrm{BP}$. Table 1 shows the ${ }^{14} \mathrm{C}$ ages of these samples.

TABLE $1 .{ }^{14} \mathrm{C}$ Age of Humic Acids of Buried and Background Chernozems (yr BP)

\begin{tabular}{lllrrr}
\hline $\begin{array}{l}\text { Depth } \\
(\mathrm{cm})\end{array}$ & $\begin{array}{l}{ }^{14} \mathrm{C} \text { age of } \\
\text { buried soil }\end{array}$ & $\begin{array}{l}{ }^{14} \mathrm{C} \text { age of } \\
\text { background } \\
\text { soil }\end{array}$ & $\begin{array}{l}\text { Reduced } \\
\text { age, } \mathrm{T}_{\mathrm{r}}\end{array}$ & \multicolumn{1}{c}{$\Delta \mathrm{T}_{{ }^{14} \mathrm{C}}$} & $\mathrm{T}_{\text {his }}$ \\
\hline $0-10$ & $4440 \pm 70$ & $1000 \pm 40$ & 1000 & 0 & 0 \\
$30-40$ & $5210 \pm 80$ & $2400 \pm 50$ & 1700 & 700 & 0.2 \\
$50-60$ & $5100 \pm 40$ & $4050 \pm 60$ & 1600 & 2400 & 0.7 \\
\hline
\end{tabular}

The Chernozem underlying the mounds before the moment of burial developed under the same conditions as the background soil. After burial, when the deposition of "young" carbon ended, transformation of specific activity occurred according to the exponential rule of radioactive decay peculiar to the closed system (Zavel'sky 1975), and the ${ }^{14} \mathrm{C}$ age of the buried soil changed proportionally to the course of true time. Consequently, the so-called reduced age, $T_{r}$, can be identified. This can be calculated by subtracting the time of burial $(3.5 \mathrm{ka})$ from the defined ${ }^{14} \mathrm{C}$ age of $\mathrm{HA}$ and the indicated ${ }^{14} \mathrm{C}$ age of the Chernozem at the moment of burial.

$\Delta \mathrm{T}_{{ }^{14} \mathrm{C}}$ expresses the increment of the ${ }^{14} \mathrm{C}$ age of the background soil (open system) over $3.5 \mathrm{ka}$, as compared to the reduced age of the buried soil, which, after burial, became a closed system. The value of $\Delta \mathrm{T}_{{ }^{4} \mathrm{C}} / \mathrm{T}_{\text {his }}$ is the gradient of radioactive age; it is defined by the relation of the increment of the radioactive age to burial time, and characterizes the extent of the association of OM of a given horizon with the closed system for which the gradient of the radioactive age is equal to one. The value of the gradient equal to zero means that humus formation in a given horizon has reached quasi-equilibrium.

As Table 1 shows, the reduced ${ }^{14} \mathrm{C}$ ages of buried soil and background are the same in the upper horizon. Chicagova and Cherkinsky (1979) showed that all the analyzed Chernozems in the upper horizon have the same specific activity, equal to the ${ }^{14} \mathrm{C}$ age of $c a .1 \mathrm{ka}$. Our experience indicates that the humus ${ }^{14} \mathrm{C}$ specific activity of the horizons that reached quasi-equilibrium remains the same with the passage of time. For such horizons, this value characterizes the duration of the cycle of complete rejuvenation of humus carbon or the maximum characteristic time of humus formation. 
On examining the change of the ${ }^{14} \mathrm{C}$ age of $\mathrm{HA}$ of lower horizons, one can see that the deeper the horizon, the larger the increment in the ${ }^{14} \mathrm{C}$ age over the past $3.5 \mathrm{ka}$ in the corresponding horizon of background soil, as compared to the reduced ${ }^{14} \mathrm{C}$ age of the buried soil. Thus, for the layer at a depth of $30-40 \mathrm{~cm}, \Delta \mathrm{T}_{14} \mathrm{C}=7 \mathrm{ka}$, i.e., the ${ }^{14} \mathrm{C}$ age of this layer changed only $0.7 \mathrm{ka}$ in $3.5 \mathrm{ka}$, whereas the gradient is near $0(0.2)$. This indicates that humus in this layer is close to dynamic equilibrium and, thus, the change in the ${ }^{14} \mathrm{C}$ age is negligible. The layer at $50-60 \mathrm{~cm}$ depth is still far from a quasi-equilibrium state; the change of the ${ }^{14} \mathrm{C}$ age over $3.5 \mathrm{ka}$ is $2.4 \mathrm{ka}$, whereas the value of the ${ }^{14} \mathrm{C}$ age gradient reached 0.7 . This value makes it quite clear how close HAs of a given horizon are to the closed system and their ${ }^{14} \mathrm{C}$ age is to the true one. The ${ }^{14} \mathrm{C}$ age of humus that has reached quasi-equilibrium indicates the characteristic time of humus formation or the duration of the humus development stage in a given horizon, enabling us to determine the rate of humus rejuvenation. For the horizons that have not reached quasi-equilibrium with ${ }^{14} \mathrm{C}$, the minimum interval for humus formation is established, whereas the farther the horizon is from equilibrium, the closer is the value of the ${ }^{14} \mathrm{C}$ age to the true one.

\section{PREPARATION OF SOIL FOR RADIOCARBON DATING}

To identify the oldest fraction of the OM of soil, Chichagova and Levitan (1966) carried out the fractionation to fulvic acids, HA and humin, according to the Kononova-Bel'chikova system. Scharpenseel (1971) attempted to determine the ${ }^{14} \mathrm{C}$ age of humus in fractions of different granulometric composition. Scharpenseel and Schiffman (1977) dated HA with different molecular masses in Podzol and Chernozem; fractions retained by sephadex G-50 with a molecular mass $<30000 \mathrm{D}$ proved to be older in both soils. Arslanov and Kozyreva (1976) attempted to extract HA preparations by boiling soils in $2 \%$ alkali (solution 1:5) and dating the extracts. From the literature and our own research, we decided to study the extract of $\mathrm{OM}$ fractions in relation to the mineral component of soil, which made it possible to solve several genetic and evolutionary problems. Generally, the oldest fractions prove to be fractions of HA, varying with type of soil (Table 2). Gerasimov and Chichagova (1971) showed that in dating Chernozems, the HA bind with calcium, which is common in some soils. In Dernopodzolic soils, the oldest prevailing fraction is free and loosely bonded HA; in hydromorphic and semihydromorphic Podzols, it is fulvic acids (Tolchel'nikov and Kostarev 1979). We believe, for any soil, the dominant fraction of HA provides the best dates, because it is the most stable in enduring continual accumulation of more recent deposits. and thus, it is the oldest fraction.

We selected the following procedure for extracting HA: after wet screening and removal of rootlets, the soil was decalcinated. Then $\mathrm{HA}, 0.1 \mathrm{~N} \mathrm{NaOH}$, were extracted from the soils (solution $=1: 20$ ). $\mathrm{HA}$ were precipitated with concentrated $\mathrm{H}_{2} \mathrm{SO}_{4}$, then washed and dried. Fulvic acids were precipitated from the neutral solution with $\mathrm{Fe}$ and $\mathrm{Al}$ salts in the form of fulvates and dried.

In recent years, we have been able to determine the oldest fraction of humus by using $6 \mathrm{~N} \mathrm{HCl}$ for hydrolysis. Under these conditions, the whole mass of $\mathrm{OM}$ is hydrolyzed without preliminary separation (Martel and Lasalle 1977). We tried to identify the biologically inert carbon in the oldest fraction of humus by Gerasimov's (1969) method, in which HA of Chernozem and Dernopodzolic soil were hydrolyzed. The dried preparation of $\mathrm{HA}$ was treated with $6 \mathrm{~N} \mathrm{HCl}$ for $24 \mathrm{~h}$ at $98^{\circ}-100^{\circ} \mathrm{C}$ during constant mixing. The non-hydrolyzed fraction of HA (NHP HA) was then washed to $\mathrm{pH}$ 5 , dried and its ${ }^{14} \mathrm{C}$ concentration measured. By dating the NHP HA and the fractions of hydrolyzed carbon in the $\mathrm{HA}$, the ${ }^{14} \mathrm{C}$ age of hydrolyzate was calculated. 
TABLE 2. Radiocarbon Ages of Fractions of Recent and Fossil Soils

\begin{tabular}{|c|c|c|c|c|c|c|c|}
\hline \multirow[b]{2}{*}{ Soil } & \multirow{2}{*}{$\begin{array}{l}\text { Depth } \\
(\mathrm{cm})\end{array}$} & \multirow[b]{2}{*}{ Total OM } & \multicolumn{3}{|c|}{ Fractions of humic acids } & \multirow[b]{2}{*}{ Fulvic acids } & \multirow{2}{*}{$\begin{array}{c}\text { Insoluble } \\
\text { residual } \\
\text { humin }\end{array}$} \\
\hline & & & 1 & 2 & 3 & & \\
\hline \multirow[t]{2}{*}{ Dernopodzol } & $2-11$ & $--^{*}$ & $--^{*}$ & \multicolumn{2}{|c|}{ Contemporary } & -- & -- \\
\hline & $34-45$ & -- & $880 \pm 30$ & \multicolumn{2}{|c|}{ Contemporary } & -- & -- \\
\hline Podzol & $33-43$ & -- & $50 \pm 30$ & -- & -- & $300 \pm 30$ & -- \\
\hline Podzol** & -- & -- & $1470 \pm 20$ & -- & -- & $2110 \pm 90$ & -- \\
\hline Peat gley & $40-50$ & -- & $8300 \pm 130$ & \multicolumn{2}{|c|}{$7600 \pm 20$} & -- & -- \\
\hline $\begin{array}{l}\text { Slightly Podzo- } \\
\text { lic Zheltozem } \dagger\end{array}$ & $20-30$ & -- & $3540 \pm 40$ & \multicolumn{2}{|c|}{$2800 \pm 40$} & -- & -- \\
\hline $\begin{array}{l}\text { Strongly Pod- } \\
\text { zolic Zhelto- } \\
\text { zem† }\end{array}$ & $20-30$ & -- & $460 \pm 40$ & \multicolumn{2}{|c|}{ Contemporary } & -- & -- \\
\hline \multirow{2}{*}{$\begin{array}{l}\text { Deep } \\
\text { Chernozem }\end{array}$} & $0-10$ & Contemporary & - & $1000 \pm 40$ & -- & -- & Contemporary \\
\hline & $50-60$ & $2890 \pm 100$ & -- & $4050 \pm 60$ & -- & $2450 \ddagger$ & $1190 \pm 100$ \\
\hline Chernozem & $12-18$ & -- & -- & $1600 \pm 40$ & -- & -- & -- \\
\hline $\begin{array}{l}\text { Mountainous } \\
\text { Chernozem }\end{array}$ & $0-17$ & -- & $940 \pm 120$ & $5100 \pm 100$ & $590 \pm 80$ & -- & -- \\
\hline Cinnamonic & $1-14$ & -- & $550 \pm 100$ & $100 \pm 100$ & -- & -- & -- \\
\hline $\begin{array}{l}\text { Holocene } \\
\text { buried }\end{array}$ & -- & -- & $190 \pm 90$ & $7710 \pm 50$ & -- & -- & -- \\
\hline Bryansk fossil & -- & -- & -- & $24,210 \pm 270$ & $24,300 \pm 360$ & -- & -- \\
\hline
\end{tabular}

\footnotetext{
*Undefined

**Tolchel'nikov and Kostarev (1979)

†Subeliani (1983)
}

$\ddagger$ Calculated to data

\section{RADIOCARBON DATING HUMUS FORMATION}

HA existing in soils for thousands of years provide them with stability and buffering. Although the non-specific humic components of HA are often the most active, they can control the specific biochemistry in any given period of time. The most important typical features of soils are related to HA. They "record" evolutionary changes that the soil has undergone during its existence.

Orlov (1974) outlined the generalized structural formula of HA. The HA molecule consists of nuclear and peripheral structural components. The nuclear, or non-hydrolyzed, part of the molecule consists of condensed aromatic rings, connected by short hydrocarbon chains or oxygen and nitrogen bridges. The "nucleus" shows considerable resistance to microorganisms and typically has ${ }^{14} \mathrm{C}$ ages $10-15 \%$ older than the HA themselves (Table 3). The peripheral part of the molecule, consisting of amino acids, and polysaccharide and aliphatic compounds, is more active; it is easily exposed to the action of microorganisms. Along the whole $\mathrm{A} 1$ ' horizon, the ${ }^{14} \mathrm{C}$ age is close to the contemporary level, which is not older than a few hundred years. Thus, this horizon is active biochemically, but the participation of the hydrolyzed and non-hydrolyzed HA are not equal.

The HA of $A 1^{\prime \prime}$ and $\mathrm{AB}$ horizons, which are the oldest ones, obviously, leave the sphere of biological cycle and become biologically inert (Gerasimov 1969). Here, the ${ }^{14} \mathrm{C}$ age of $\mathrm{HA}$ and their 
TABLE 3. Radiocarbon Ages of Different Soil Horizons

\begin{tabular}{llcccc}
\hline & & \multirow{2}{*}{ Soil } & Horizon & Depth & \multicolumn{3}{c}{${ }^{14} \mathrm{C}$ age } \\
\cline { 5 - 6 } & & $(\mathrm{cm})$ & HA & NHP HA & Hydrolyzate \\
\hline Typical Cher- & A1' & $0-10$ & $1000 \pm 40$ & $1100 \pm 30$ & 720 \\
nozem, Kursk & & $10-20$ & $1440 \pm 50$ & $1980 \pm 30$ & Contemporary \\
region & & $30-40$ & $2400 \pm 50$ & $2660 \pm 40$ & 300 \\
& $\mathrm{~A} 1{ }^{\prime \prime}$ & $50-60$ & $4050 \pm 60$ & $4230 \pm 40$ & 3170 \\
Dernopodzol, & $\mathrm{AB}$ & $70-80$ & $4580 \pm 60$ & $5070 \pm 50$ & 3670 \\
Vladimir & $\mathrm{A} 1$ & $0-3$ & Contemporary & Contemporary & -- \\
district & $\mathrm{A} 1 \mathrm{~A} 2$ & $3-9$ & Contemporary & Contemporary & - \\
\hline
\end{tabular}

fragments grows significantly. The age of the hydrolyzed part of the molecule is much older than that in the upper horizon, 3170 and $3670 \mathrm{yr}$, respectively.

HA from the humus-accumulative horizons of Dernopodzolic soil differ from Chernozems in that they have lower carbon content and higher hydrolyzed content. The ${ }^{14} \mathrm{C}$ age of HA and their fractions of Dernopodzolic soils proved to be contemporary. Thus, the rate of HA carbon rejuvenation in $\mathrm{A} 1^{\prime}, \mathrm{A} 1$ and $\mathrm{A} 2$ horizons is extremely high for the nucleus and periphery of the molecule, which reproduces dozens of times, perhaps in the first few hundred years, probably replacing the HA molecules completely.

Fokin (1975) proposed the following hypothesis for the mechanism of humus rejuvenation:

1. Fragmentary rejuvenation consists of the separation of the periphery of the molecule due to the action of microorganisms and fermentation, and inclusion into already-formed monometric molecules of non-humus matter and rejuvenation as a result of the exchange reaction between the peripheral fragments of the "young" and the "old" HA or radicals of pro-humus matter.

2. Sorption-molecular rejuvenation occurs with both sorption from solutions of HA newly formed in the upper horizons or partially renewed humus molecules of the mineral solid phase of soils as well as with the change of humus molecules connected with it by the renewed humus molecules introduced to the soil solution.

Our dating results demonstrate that, from the upper part of the humus profile of Chernozem to a depth of $30-40 \mathrm{~cm}$, the HA rejuvenation process is mainly fragmentary because the hydrolyzed part of the HA is continually renewed and has a contemporary ${ }^{14} \mathrm{C}$ age. In the lower horizons ( $\mathrm{A} 1{ }^{\prime \prime}$, $\mathrm{AB}$ ), the rejuvenation mechanism is also largely fragmentary. The hydrolyzate is much younger than the non-hydrolyzed part and the $\mathrm{HA}$ themselves, which is possibly due to partial rejuvenation of the peripheral fragments whose ${ }^{14} \mathrm{C}$ ages differ from the contemporary ones. Fragmentary rejuvenation also becomes less important, and the process of molecular-sorption rejuvenation becomes more important.

In the humus-eluvial horizons of Dernopodzolic soils, where HA and their non-hydrolyzed fractions have contemporary ${ }^{14} \mathrm{C}$ ages, the rejuvenation mechanism is primarily sorption-molecular. Slightly humified HA molecules, which can hydrolyze up to $\sim 50 \%$, become quickly mineralized, or leave the eluvial horizons, and are continually replaced by fresh HA formed in the same way. Apparently, the process of fragmentary rejuvenation in this soil is not of vital significance. 
The ${ }^{14} \mathrm{C}$ age of $\mathrm{OM}$ can be used to indicate the depth of humification (Orlov 1977) and the degree of humus preservation, because it reflects changes in such kinetic control parameters as the intensity of the processes of humification and humus rejuvenation. During the investigation of ${ }^{14} \mathrm{C}$ age of HA in the upper soil horizons, characterized by the duration of biological activity, indicated by the differences of hydrothermal factors, we made the following observations.

In arctic and tundra soils, the rate of carbon exchange is slow and the ${ }^{14} \mathrm{C}$ age of Horizons $\mathrm{A} 0-\mathrm{A} 2$ of arctic podbur is $3700 \mathrm{yr}$. With the increase of biological activity in forest soils, the rate of the carbon cycle increases, and the ${ }^{14} \mathrm{C}$ age of the upper horizons of Dernopodzolic and gray forest soils becomes contemporary. In Chernozems, where biological activity is maximum, ${ }^{14} \mathrm{C}$ age should be minimal. However, because of stronger bonds of HA with the minerals in the soil, and their thermodynamic stability determined by characteristics of the HA structure of Chernozem, their ${ }^{14} \mathrm{C}$ age is older than that of the HA of forest soils, $\sim 1 \mathrm{ka}$ (Cherkinsky 1981). The ${ }^{14} \mathrm{C}$ ages of humus horizons of chestnut soils are similar to those of Chernozems (Rubilin and Kozyreva 1980).

\section{SOIL HUMUS RADIOCARBON DATING IN PEDOLOGY AND PALEOGEOGRAPHY}

As shown above, the dating of contemporary soil humus has made it possible to study certain mechanisms and rates of humus formation by analyzing the divergent ages of $\mathrm{OM}$ in a profile, horizon, fraction and fragment. Research of the genesis and transformation of $\mathrm{OM}$ through ${ }^{14} \mathrm{C}$ measurements and physical and chemical analysis of humus shows that the HA molecule gets more complex with age. Carbon content increases, whereas nitrogen content decreases. Aromaticity and oxidability increase, whereas dispersibility decreases (Chichagova 1985).

The dating of Dernopodzolic soils illustrates the dependence of the rate of carbon exchange on relief and soil moisture content. Better preservation of humus and slower rate of exchange are observed in Dernopodzol-gley located at the base of a slope in conditions of increased hydromorphism. The ${ }^{14} \mathrm{C}$ age of Horizon $\mathrm{A} 1 \mathrm{~B} 1_{\mathrm{g}}$ is $8440 \mathrm{yr}$. Under automorphic conditions, a stratigraphically single-age horizon yields a ${ }^{14} \mathrm{C}$ age of humus at $4400 \mathrm{yr}$ (Table 4).

Differences in the ${ }^{14} \mathrm{C}$ age of sandy Podzol and Podzolic soil on covering loam relate to the differences in granulometric composition of soil-forming rocks, which also affects the rate of carbon exchange. Humus horizons of sandy soils are younger than those of loamy composition (Tolchel'nikov and Kostarev 1982).

TABLE 4. ${ }^{14} \mathrm{C}$ Ages of Straw-Yellow Dernopodzolic and Sod-Gley Soils

\begin{tabular}{lllcc}
\hline \multicolumn{1}{c}{ Soil } & \multicolumn{1}{c}{ Location } & Horizon & Depth $(\mathrm{cm})$ & Age (yr) \\
\hline Straw-yellow & Section 2-71, & A1 & $2-5$ & Contemporary \\
$\begin{array}{l}\text { Dernopodzol on } \\
\text { cover loam }\end{array}$ & Yaroslavl' district & A1A2 & $5-11$ & $600 \pm 30$ \\
& & A2 & $11-27$ & $1180 \pm 20$ \\
& & A2 $2-A 2 B 1$ & $33-51$ & $4440 \pm 30$ \\
Straw-yellow & Section 2-71a, & A2B ${ }^{\mathrm{h}}$ & $20-27$ & $5860 \pm 60$ \\
$\begin{array}{l}\text { Dernopodzol on } \\
\text { cover loam }\end{array}$ & Yaroslavl' district & & & \\
$\begin{array}{l}\text { Sod-gley on } \\
\text { cover loam }\end{array}$ & Section 2-72, & A1 & $0-10$ & Contemporary \\
& Yaroslavl' district & (A0) & $20-30$ & $4000 \pm 50$ \\
& & (A1B1 $\left.1_{\mathrm{g}}\right)$ & $30-35$ & $8440 \pm 60$ \\
\hline
\end{tabular}


${ }^{14} \mathrm{C}$ dating and analysis of the composition of Dernopodzolic humus enable us to identify relict features of the second humus horizons, which varied in degree of preservation. The extent of the rejuvenation of ${ }^{14} \mathrm{C}$ dates is difficult to determine, because it depends on associating dates with soils differing in properties and development, and on the extent of the contemporary Podzolic process (Table 5). However, we assume that the ages of relict horizons are similar to those of buried Holocene paleosols.

TABLE 5. ${ }^{14} \mathrm{C}$ Age of Secondary Podzolic and Dernopodzolic Soils in the Second Humus Horizon

\begin{tabular}{lllccl}
\hline \multicolumn{1}{c}{ Soil } & \multicolumn{1}{c}{ Location } & Horizon & Depth (cm) & Age (BP) & Sample no. \\
\hline $\begin{array}{l}\text { Derno-secondary: } \\
\text { moderately Podzolic on }\end{array}$ & Tomsk district & A1 & $5-10$ & $890 \pm 130$ & LU-117 \\
carbonate loam & & A2 $^{\mathrm{h}}$ & $35-40$ & $3970 \pm 120$ & LU-119 \\
$\begin{array}{l}\text { Derno-secondary: } \\
\text { strongly Podzolic }\end{array}$ & Tomsk district & A1 & $4-9$ & $1920 \pm 140$ & LU-120 \\
Dernopodzolic in the & Tomsk district & A1 & $3-12$ & $1230 \pm 80$ & Mo-462 \\
second humus horizon & & A2 & $32-42$ & $7000 \pm 160$ & Mo-463 \\
Dernopodzolic on cover & Tyumen' district, & A1-A2 & $4-19$ & $350 \pm 50$ & IGAN-232 \\
loam & Sec. 1-77 & A $^{\mathrm{h}}$ A2 & $19-30$ & $2930 \pm 60$ & IGAN-233 \\
Straw-yellow Derno- & Tyumen' district, & A1 & $23-30$ & $850 \pm 30$ & IGAN-217 \\
podzolic on cover loam & Sec. 87-A7 & A2 & $30-35$ & $7000 \pm 50$ & IGAN-214 \\
\hline
\end{tabular}

The basic features of Holocene soil had already formed by the end of the Atlantic climatic optimum (AT-II) $>5 \mathrm{ka}$ ago. We find traces of humus horizons of these Holocene paleosols in the profiles of contemporary Dernopodzolic soil in the second humus horizons. Colder temperature, increased continentality and humidity during the Postatlantic incurred further degradation of second humus horizons and decreased ${ }^{14} \mathrm{C}$ ages. The preservation of relict horizons in contemporary soils enables us to understand the history of their development.

${ }^{14} \mathrm{C}$ dating of Chernozem humus has led us to the following observations on the distribution of ${ }^{14} \mathrm{C}$ dates of Chernozems:

1. The upper 10-cm humus horizon dates to $\sim 1 \mathrm{ka}$, which is characteristic of the given types of soils, and indicates the rate of carbon exchange in a given biocoenosis.

2. The middle part of a humus horizon is $\sim 1 \mathrm{ka}$ older than the upper part, whereas beyond the active part of a humus horizon, the ${ }^{14} \mathrm{C}$ age abruptly increases to $4-5 \mathrm{ka}$. This suggests a reduction of biochemical activity and better preservation of relict carbon remaining from former periods of soil formation. On the other hand, the age difference represents complexities of the nature and properties of HA with depth, along with the HA's greater "chemical" maturity.

3. The lower part of a profile (beyond the humus horizon) is $>6 \mathrm{ka}$, which may represent the rate of the pedalogical carbon cycle, although the ${ }^{14} \mathrm{C}$ age is clearly too young (Gerasimov 1971).

The ${ }^{14} \mathrm{C}$ age of $\mathrm{HA}$ of the upper part of a humus horizon also provides information on the rate of the biological carbon cycle, i.e., the relative age of soils (Gerasimov 1969). The ${ }^{14} \mathrm{C}$ age of relict carbon preserved in the lower part of the Chernozem, where HA approximate a closed system, may represent the minimum absolute age or the minimum duration of the lower soil horizon. 
We present two conceptual models of age correlation with depth of a soil profile. In the first, Gerasimov (1969) suggests that soils grow upward due to eolian deposits, and thus, the carbon of the lower part of a profile goes beyond the sphere of the biological cycle and becomes relict. Therefore, the ${ }^{14} \mathrm{C}$ age increases with depth. The second conceptual model (M. A. Glazovskaya, personal communication) explains the increase in age with depth by the reduction of biochemical activity in HA and growth of their thermodynamic stability due to decreased sources of fresh carbon from plants and other origins at increased depth. This hypothesis confirms the possibility of "development" of a soil profile, demonstrated by the leveling of a ${ }^{14} \mathrm{C}$ profile (sequence of dates) due to varying activity rates of carbon in the subhorizons of humus in the biocycle and different "rejuvenation" patterns. In this case, the possibility of eolian deposits is not ruled out; thus, the second concept supplements the first (in fact, one or the other may dominate, depending on the geological setting).

Dating humus by ${ }^{14} \mathrm{C}$ and paleogeographical methods enables us to identify trends in the development of climate, vegetal cover and soils of the forest-steppe area during the Holocene. The transformation of vegetation occurs within the framework of a forest-steppe landscape, whereas soils evolve within the limits of one soil type. The shift toward greater humidity at the end of the Atlantic-beginning of the Subboreal climatic zone contributed to increased growth of herbs in steppe cenosis (meadow cover) and the transformation of Chernozems from the ordinary into typical Chernozems.

${ }^{14} \mathrm{C}$ ages of subkurgan soils confirm trends defined in the development of the Holocene. Thus, dating the humus of Chernozems of the central forest-steppe, along with palynological and paleopedological data allow us to identify a pattern of soil evolution, from Chernozem-like soil in Preboreal and Boreal periods, through the southern and ordinary Chernozems in the Atlantic, to typical and deep Chernozems in the Subboreal and Subatlantic.

Dating the humus of rock soils of the Greater Caucasus shows that ${ }^{14} \mathrm{C}$ ages are affected by the extent of exogenic disturbances. If the age of the humus of the upper horizons is determined by the carbon exchange rate of HA peculiar to the given type of soils (from $\sim 0.2-1.7 \mathrm{ka}$ ), the age of the lower horizons in various geomorphological areas depends mostly upon exogenic natural disturbances. The ages range from the $\sim 1 \mathrm{ka}$ at the steepest slopes to $9 \mathrm{ka}$ at the flat cuestas of the Pastbishchny Ridge, remarkable for its stable soil cover (Romashkevitch, Chichagova and Cherkinsky 1984). The ${ }^{14} \mathrm{C}$ age of humus horizons of Zheltozem Podzolic soils of the Georgian subtropics, $\sim 0.1 \mathrm{ka}$, is close to that of Podzolic and Dernopodzolic soils of the East-European Plain (Subeliani 1983).

The geographical distribution of ${ }^{14} \mathrm{C}$ ages of humus of fossil soils for the Briansk period on the East-European Plain and their equivalents in western Siberia, Europe and North America shows practically no differences, ranging from 22 to $32 \mathrm{ka}$ ago. This supports stratigraphic conformity of the horizon and synchronism of the last Ice Age in various areas (Velichko and Morozova 1976; Chichagova 1972). Some differences in the dates for this horizon reflect, on the one hand, different levels of preservation of the soil profile, and on the other hand, possible regional differences in the character and rate of soil formation during the Briansk (Table 6).

The data on humus properties and ${ }^{14} \mathrm{C}$ age of Holocene paleosols and dark-colored buried horizons of the central part of the East-European Plain, dated to the late AT, indicate the existence, at that time, of the dark-colored stage of soil formation in the southern taiga of the Russian Plain (Alexandrovsky 1983). 
TABLE 6. ${ }^{14} \mathrm{C}$ Ages of Humus of Briansk Fossil Soil on the East-European Plain and its Analogs in Western Siberia, Europe and North America

\begin{tabular}{|c|c|c|c|c|c|}
\hline Site & Soil layer & Depth (m) & Material & Sample no. & Age \\
\hline $\begin{array}{l}\text { Arapovichi, } \\
\text { Chernigov district }\end{array}$ & Briansk soil & $7.9-8.0$ & HA-II & IGAN-46 & $24,000 \pm 300$ \\
\hline $\begin{array}{l}\text { Mezin, Chernigov } \\
\text { district }\end{array}$ & -- & 3.2 & HA-II-III & IGAN-88 & $24,300 \pm 370$ \\
\hline $\begin{array}{l}\text { Novokhopersk, } \\
\text { Voronez district }\end{array}$ & -- & 6.0 & HA-II-III & IGAN-87 & $22,870 \pm 220$ \\
\hline Basov kut, Rovno & Dubnovsk soil & 9.0 & HA-II-III & IGAN-74 & $28,400 \pm 850$ \\
\hline $\begin{array}{l}\text { Mezherichi, } \\
\text { Cherkassk district }\end{array}$ & Briansk soil & 9.0 & HA-II-III & IGAN-337 & $25,150 \pm 740$ \\
\hline $\begin{array}{l}\text { "Mramorny" quarry, } \\
\text { Novosibirsk district }\end{array}$ & Upper Iskitim soil & 3.8 & HA-II & IGAN-167 & $26,300 \pm 700$ \\
\hline $\begin{array}{l}\text { "Mramorny" quarry, } \\
\text { Novosibirsk oblast }\end{array}$ & Lower Iskitim soil & $4.0-4.5$ & HA-II-III & IGAN-168 & $29,000 \pm 450$ \\
\hline $\begin{array}{l}\text { Dolni Vestonitsy } \\
\text { stand, CSSR }\end{array}$ & $\begin{array}{l}\text { Cultural layer, soil } \\
\text { complex RK-1 }\end{array}$ & -- & Humus & LrN-2092 & $26,300 \pm 300$ \\
\hline $\begin{array}{l}\text { Gettwein-Aigen, } \\
\text { Germany }\end{array}$ & $\begin{array}{l}\text { Humus horizon of } \\
\text { Sttillfrid B soil } \\
\text { complex }\end{array}$ & -- & Humus & $\mathrm{LrN}-4556$ & $22,600 \pm 250$ \\
\hline Illinois, USA & $\begin{array}{l}\text { Humic horizons of } \\
\text { Farmdail } \\
\text { interstadial }\end{array}$ & -- & Humus & LrN-1908 & $23,940 \pm 1000$ \\
\hline
\end{tabular}

\section{CONCLUSION}

${ }^{14} \mathrm{C}$ research of Late Pleistocene and Holocene fossil soils and cultural horizons of archaeological sites helps establish the geochronology of these periods. We are able to use our results in reconstructing and modeling natural and climatic changes, and in the correlation with human prehistory in the northern hemisphere. ${ }^{14} \mathrm{C}$ soil dating is complex and requires further study. However, ${ }^{14} \mathrm{C}$ data can help resolve problems of genesis and evolution, humus formation and metamorphism of $\mathrm{OM}$ in the humus of contemporary and fossil soils. It can also help us understand the geochronology and stratigraphy of the Late Pleistocene and Holocene. Such information is possible only through thorough analysis of each ${ }^{14} \mathrm{C}$ profile, paleogeographical data and models of carbon exchange for every type of profile, monogenetic and polygenetic, as well as by dating corresponding samples.

\section{REFERENCES}

Alexandrovsky, A. L. 1983 Evolution of Soils of the East-European Plain in the Holocene. Moscow, Nauka: $150 \mathrm{p}$.

Arslanov, Kh. A. and Kozyreva M. G. 1976 On the matter of dating contemporary soils by the radiocarbon method. In Problems of Palaeogeography and Geochronology of the Upper Pleistocene and Holocene of the Northwest Russian Plain 10. Leningrad: 99-113.

Cherkinsky, A. E. 1981 Recent theories of humification and radiocarbon research of some types of soils. Doklady Akademii Nauk SSSR 258(4): 993-996.

Chichagova, O. A. 1972 On the age of the Upper Pleistocene fossil soils on the basis of radiocarbon data. In Loesses, Buried Soils and Cryogenic Developments on the Russian Plain. Moscow, Nauka: 119-137. 
Chichagova, O. A. 1985 Radiocarbon Dating of Humus of Soils: Methods and Applications in Pedology and Palaeogeography. Moscow, Nauka: 155 p.

Chichagova, O. A., Ammosova, Ya. M. and Aleksandrovsky, A. L. 1979 Research of organic matter of fossil soils of various ages. In Accumulation and Transformation of Sedikakhits. Moscow, Nauka: 8186.

Chichagova, O. A. and Cherkinsky, A. E. Radiocarbon research of organic matter and age of soils. Biological Sciences 8: 5-18.

Chichagova, O. A. and Levitan, D. G. 1966 The experience of applying the radiocarbon method for determining the age of soils. Izvestiya Akademii Nauk SSSR, Seriya Geografischeskaya i Geofizicheskaya 2: 80-84.

Fokin, A. D. (ms.) 1975 Study of the Processes of Transformation, Interaction and Transfer of Organic Matter, Iron, and Phosphorus in Podzolic Soil. Ph.D. dissertation, Moscow Institute of Geography: $28 \mathrm{p}$.

Gerasimov, I. P. 1969 Absolute and relative age of soils. Pochvovedenie 5: 27-32.

1971 Nature and essence of ancient soils. Pochvovedenie 4: 3-10.

Gerasimov, I. P. and Chichagova, O. A. 1971 Some problems of radiocarbon dating of soil humus. Pochvovedenie 10: 3-11.

Lobo, P. F. S. and Flexor, L. M. 1974 Essai de détermination du temps de résidence des fractions humiques de deux sols ferrallitiques par l'utilisation de radiocarbone naturel et thermonucléaire. Cahiers ORSTOM, Série Pédologie 12(1): 115-123.

Martel, J. A. and Lasalle, P. 1977 Radiocarbon dating of organic matter from a cultivated topsoil in eastern Canada. Canadian Journal of Soil Sciences 57(3): 335-377.

Orlov, D. S. 1974 Humic Acids of Soils. Moscow State University: $333 \mathrm{p}$.

1977 The kinetic theory of humification and pattern of possible structure of humic acids. Scientific
Reports of the Higher School of Biological Sciences 9: 5-16.

Romashkevitch, A. I., Chichagova, O. A. and Cherkinsky, A. E. 1984 Age of humus of mountain soils of the Greater Caucasus. Pochvovedenie 3: 23-30.

Rubilin, E. V. and Kozyreva, M. G. 1980 On the age of chestnut soils of the European part of the USSR. Pochvovedenie 1: 5-13.

Scharpenseel, H. W. 1971 Radiocarbon dating of soils -problems, troubles, hopes. In Paleopedology: Origin, Nature and Dating of Paleosols. Jerusalem: 77-88.

Scharpenseel, H. W. and Schiffman, H. 1977 Radiocarbon dating of soils, a review. Zeitschrift für Pflanzenernährung und Bodenkunde 149: 159-174.

Sokolova, I. A. and Targul'yan, V. O. 1976 Interrelation between soil and environment: Soil-memory, soilmoment. In Study and Development of the Natural Environment. Moscow, Nauka: 150-164.

Subeliani, T. M. (ms.) 1983 The Role of Age in Forming Subtropic Zheltozem-Podzolic Soils: Ph.D. dissertation, Tbilisi University.

Targul'yan, V. O. 1982 Development of soils in time. In Problems of Pedology. Moscow, Nauka: 108-113.

Tolchel'nikov, Yu. S. and Kostarev, A. S. 1979 Experience in determining the age of alfehumic Podzol by the radiocarbon method. Izvestiya Vsesoyuznogo Geograficheskogo Obschestva 11(3): 264-270.

1982 On the interpretation of radiocarbon dates of soils. Izvestiya Vsesoyuznogo Geograficheskogo Obschestva 11(3): 264-270.

Velichko, A. A. and Morozova T. D. 1976 Peculiarities of paleogeographical approach when studying fossil and contemporary soils. In Study and Development of the Natural Environment. Moscow, Nauka: 108-123.

Zavel'sky, F. S. 1975 Radiocarbon dating and theoretical models of the carbon cycle in soils. Izvestiya Akademii Nauk SSSR, Seriya Geografischeskaya i Geofizicheskaya 1: 27-34. 